UDC 37.04:065:014

I. Dobroskok, Dr. Sc. (Pedag.), Prof., orcid.org/0000-0002-3937-8428,

L. Basiuk, Cand. Sc. (Pedag.), orcid.org/0000-0003-0899-8648, N. Rzhevska, Cand. Sc. (Pedag.), orcid.org/0000-0001-8695-5964, M. Kalashnyk, orcid.org/0000-0001-7015-3641
DOI: $10.29202 /$ nvngu/2019-3/20

Pereiaslav-Khmelnytskyi Hryhorii Skovoroda State Pedagogical University, Pereiaslav-Khmelnytskyi, Ukraine, e-mail: mfkoorg@gmail.com

\title{
RECLAIMING AND REFRAMING ECONOMICS: PROBING THE EDUCATIONAL POTENTIAL
}

Purpose. To consider the possibilities of educational potential in the reclaiming and reframing of the world economy. The authors paid special attention to the activities of the club of Rome, the examples of which the possibilities of educational potential for the reform of the world economy were revealed.

Methodology. As a theoretical and methodological basis of the study, the authors used the activities of the club of Rome, an authoritative political, scientific and financial organization, which considers the reclaiming and reframing economics to be one of the main objectives of its activities. The main methods of research are: methods of analysis and synthesis, comparative analysis, methods of expert assessments and scientific generalizations.

Findings. The authors made a brief review of modern literature, which proves that the imperfection of the current economic system is the main cause of climate change, depletion of natural resources, as well as growing social inequality in society. By the example of the club of Rome, the authors proved that the reclaiming and reframing of the world economy should begin with education. Together with political, financial and scientific potentials, educational potential has had and continues having a powerful impact on the reclaiming and reframing of the world economy. The authors identified and proved two key opportunities of educational potential:

1. An opportunity to change the world Outlook on the economy on a social scale, i.e. to change the philosophy of the economy.

2. An opportunity to create a global youth network that has the power to rebuild and reform the economic system.

Originality. The authors identified and proved two key opportunities of educational potential in the reclaiming and reframing of the world economy: 1 . An opportunity to change the worldview of the economy on a social scale, i.e. to change the philosophy of the economy. 2. An opportunity to create a global youth network that has the power to rebuild and reform the economic system.

Practical value. By the example of the projects of the club of Rome, the authors proved the effectiveness of the educational potential in the reclaiming and reframing of the world economy. The results of the research open the possibility of wide use of the experience of the club of Rome both for reforming the economic discipline in the educational system of Ukraine and for reforming the economy of Ukraine. The paper is intended for theoretical exploration and practical use of students, graduate students and teachers of Economics, as well as second persons interested in reforming the world economy and sustainable development of society.

Keywords: global economy, economic system, reframing economics, Club of Rome, educational potential, sustainability, youth movement

Introduction. In the last few decades, the mainstream of scientific publications has been devoted to the issues of reclaiming and reframing of the world economy. We highlight the book "Reclaiming Pluralism in Economics", which is based on the rich heritage of literature on the history of Economics and focuses on the revival of pluralism in the economy. The editors of the book, today's authoritative economists, are trying to restore the authority of economic schools, which modern neoclassical Economics declared "heterodox." The content of the book is aimed at the revival of pluralism in economic discipline as a basis, not a challenge to the mainstream [1].

In the books "Reframing Economics: Economic Action as Imperfect Cooperation" [2] and "Reframing Economic Policy towards Sustainability" [3] the authors reveal the imperfection of the world economy in

(C) Dobroskok I., Basiuk L., Rzhevska N., Kalashnyk M., 2019 the context of globalization. The books emphasize the inability of modern, so-called "Orthodox" economic theories to ensure sustainable development of society. The authors suggest radical transformations in the economy, which are based on the political and economic impasse, as a way out of the existing political and economic impasse:

1. Return to the history of economic thought and rethinking of the modern economy and its future with the involvement of "Orthodox" and declared "heterodox" economic theories.

2. The revival of pluralism in the economy; the rejection of the understanding of Economics as a mathematical discipline, and the return of wealth to the economy of its original meanings, such as "an inquiry into the nature and causes of the wealth of nations".

The imperfection of the modern economic system and the devastating consequences for society of the use 
of "Orthodox" economic theories are highlighted on a large scale in the activities of the authoritative club of Rome in economic science and business. The history of the club of Rome began in 1967, with the creative Union of the successful Italian entrepreneur Aurelio Peccei, who over the years held leading management positions in the automotive, aviation, banking and information technology corporations, and the Scottish chemist Alexander King, who was an authoritative European official specializing in the promotion of scientific and industrial research in Europe and the world. The halfcentury history of the club of Rome testifies to the successful symbiosis of business and science.

The main purpose of the club of Rome is to study the global problems facing humanity and their solutions by methods of scientific analysis. The club of Rome publishes the results of its research in peer-reviewed "Reports to the Club of Rome". The most famous Report is "The Limits to Growth", published in 1972. As of 2018, it has been translated into 30 languages and sold in more than 30 million copies [4].

One of the latest Reports of the club of Rome is called "A Finer Future: Creating an Economy in Service to Life" [5]. The authors of the report are recognized as the world experts in the field of business, economics and sustainability. In the Report, they do not only point to global problems that are clearly visible in the development of the existing economic system, but also offer solutions to these problems, inspiring optimism and the possibility of building an economy on new principles. The authors of the Report formulate the main goal that should face leaders in the field of business, Economics, politics and education - setting the course to a regenerative economy [5].

At the Club's $50^{t h}$ anniversary conference in Rome, Italy there were clearly formulated three themes, on which the Club will focus its scientific and financial potential:

1. Emerging New Civilization Initiative.

2. Reclaiming and reframing economics.

3. Climate emergency.

The main purpose of the article is to consider the possibilities of educational potential in the reclaiming and reframing economics. We will pay special attention to the activities of the club of Rome, by the examples of which we will reveal the possibilities of educational potential for reforming the world economy.

Results. As confirmed by the above-mentioned scientific research, including the Reports to the Club of Rome, the existing economic system is not only exemplary, but causes irreparable harm to humanity, endangers its future existence. The imperfection of the current economic system is the cause of climate change, depletion of natural resources, growing inequality in the scale of civilization.

It is for this reason that the reclaiming and reframing economics is a priority for all mankind. However, how to change the current economic system? What capacities need to be harnessed to achieve sustainable human development?

It should be noted that in 1990 Ricardo DiezHochleitner, a Spanish diplomat, economist and educa- tional reformist was elected President of the Club of Rome. Diez-Hochleitner has at various times held key positions related to education in international organizations, including the World Bank and UNESCO. It was under Diez-Hochleitner that the Club of Rome began to use the educational potential to promote its global ideas, as well as to reform the education itself on the basis of philosophy and achieved scientific results.

Under Diez-Hochleitner, the Club of Rome began using a new strategy: the reclaiming and reframing of the world economy should begin with education. The new strategy did not imply changes in the programs of economic specialities of educational institutions, drawing up new curricula, etc. This is, first, the scale of the activities of the club of Rome, and secondly, not the way to change the current economic system. The new strategy of the Club of Rome was aimed at the disclosure of educational potential and the use of these opportunities to achieve their goals and objectives.

We investigate the possibilities of educational potential by the examples of projects of the club of Rome. We believe that educational potential, combined with political, financial and scientific potential, has had and continues having a powerful impact on the reclaiming and reframing economics.

From our point of view, there are two key opportunities in the educational potential:

1. The opportunity to change the world Outlook on the economy on a social scale, i.e. to change the philosophy of the economy.

2. An opportunity to create a global youth network that has the power to rebuild and reform the economic system.

We will prove the opportunities of educational potential in the long-lived, by the examples of the activities of the club of Rome for the reclaiming and reframing economics.

1. The opportunity to change the world Outlook on the economy on a social scale, i. e. to change the philosophy of the economy. As we have already pointed out at the beginning of the article, the narrowing of economic discipline to the format of mathematical analysis, on the one hand, allowed the economy to be a purely scientific discipline. Modern, so-called "heterodox" economic theories use a complex mathematical apparatus, which allows them to formalize many processes of society and build realistic forecasts in certain areas of activity. However, there is another side to the formalization of economic discipline. And this side has significantly narrowed the possibilities of modern economic theories in comparison with the original theories of the so-called "political economy", most of which are now declared "heretical". This is written, for example, in the studies of G. McManners [3], N. Lovins [5], A. Kravchenko [6], and others.

Using opportunities of the educational building was started in the activities of the Club of Rome from the time of the presidency of Ricardo Diez-Hochleitner. It was originally aimed at reviving the philosophy of Economics in the traditions laid down since its inception as a "political economy". In fact, the activity of the Club of 
Rome was aimed at the revival of the philosophical approach to the study of Economics; at the revival of the so-called "Plato's line" [7, 8].

The philosophical tradition in education (or "Plato's line") provides a comprehensive coverage of the subject of study. This is not only the unity of theory and practice, but also the consideration of the subject of research in its nesting in a larger, fundamental current processes. It is for this reason that the consideration of Economics in the philosophical tradition goes far beyond mathematical analysis and any other formalization that mainstream economic theories claim. The philosophical tradition assumes consideration of a subject of research as a part of planetary processes (for example, [9]), and even space processes (for example, [19]). Therefore, the philosophy of Economics, which is promoted by certain scientists including the Club of Rome, is not limited to the study, teaching and use of economic known within the narrow boundaries of modern economic theories. It is an all-encompassing, diverse, pluralistic economic worldview that inspires and educates students, activists, intellectuals, professors and anyone for whom the well-being of people and the sustainable development of society is perceived as an individual mission, purpose.

For this purpose, on September 9-11, 2016, in the Castle Burg Feistritz (built in the $12^{\text {th }}$ century), $80 \mathrm{~km}$ from Vienna, Austria, the Roman club presented its first youth "Reclaim Economics" project. Since this project in practice reveals the possibility of educational potential to change the world Outlook on the economy in society, we consider its details.

The "Reclaim Economics" project pursued two main objectives:

1. To ensure the desire of society for change.

2. To ensure that students receive a balanced economic education.

To achieve these goals, the organizers of the project, the members of the Club of Rome, have formulated three main tasks [11]:

1. It is necessary to unite and strengthen the influence on the existing economic system in order to change it.

2 . It is necessary that young people demand pluralism from teachers in the presentation of economic ideas; teaching not only mainstream economic theories, and theories declared "heretical".

3. It is necessary to raise awareness of the shortcomings of the modern economic system and "Orthodox" economic theories.

The "Reclaim Economics" project included specific steps to achieve the goals and objectives. The authors of the project offered the students the following set of actions [12]:

1. To conduct appropriate actions on the territory of universities (campuses), for example, flash mobs, sticker campaigns, die ins.

2. To be active in the online space, for example, hashtag activism, correct, Wikipedia entries, campaign homepage.

3. To use multimedia capabilities, such as video, short films, courses, treatment actively.
4. To develop and disseminate the Toolkit among students, for example, templates for critical issues, to publish "missing pages" for mainstream books.

5. To conduct counter-information activities; for example, targeted criticism of modern academic books and textbooks use critical art installations. In this regard, the poster of the "Reclaim Economics" project is particularly indicative and eloquent: on the blue background of the ocean (the image of society), a big fish (the mainstream economic system) "runs away" from the flock of small fish chasing (the community of students and economic pluralism is known) [11].

Anyone could join the "Reclaim Economics" project. To become a part of the youth team and to regularly communicate with members of the Club of Rome, as well as with world-renowned experts-economists promoting a new philosophy of Economics, it was necessary to recognize the expediency of their actions in the direction of solving the following issues [12]:

1. Are you dissatisfied with the way economics is taught today?

2. Are you eager to challenge the current system?

3. Are you environmentally and socially aware?

4. Are you ambitious?

5. Are you determined?

6. Are you ready to commit time to the cause?

Thus, by the example of the youth "Reclaim Economics" project organized by the Club of Rome, we see that:

1. The educational potential allows us to form the worldview of Economics in the philosophical tradition: not as a dogmatic doctrine, but as a pluralism of ideas, the totality of which gives rise to the truth.

2. Educational potential forms the pluralism of the economy as the basis of the worldview of the younger generations, which in Ancient Greece was called by the term "arête" [13].

This feature of the educational potential leads to the fact that the generation that blindly believes in the truth of mainstream economic theories will be replaced by a generation that recognizes pluralism in the economy, which is ready to debate about the future of the economic system on the basis of complementary economic theories. After all, the value of economic theories is measured not by their belonging to the "Orthodox" or "heretical" directions, but by the extent to which the theory is able to ensure the sustainable development of society.

2. An opportunity to create a global youth network that has the power to rebuild and reform the economic system. Let us consider the second opportunity we have identified for the educational potential to have a powerful impact on the reclaiming and reframing of the world economy. It is an opportunity to create a global youth network that has the power to rebuild and reform the economic system. The sequence of the creation of the global youth network and its increasing power of influence is clearly seen in the projects organized by the Club of Rome. The Category: Uncategorized on the website of the Club of Rome begins with the "Reclaim Economics" project, from June 3, 2016 and ends with the project "The Club of Rome Supports Global Student 
Climate Protests", here March 14, 2019 [14]. In three years, more than 10 key events were held, as a result of which students, teachers, budding entrepreneurs, journalists and activists from all continents of our planet were involved in the work of the Club of Rome on the restoration and reframing of the world economy. The main and defining one in creating influential global youth network has resulted in the following projects:

1) on May 4, 2017, in Zaragoza, Spain, the CoChairman of the Club of Rome Ernst von Weizsäcker presented a Report COME ON! The presentation was organized mainly with the participation of young people, experts, economists, as well as officials of the industrial ministries of Spain. The participants signed the "Sustainability Declaration for Aragon" [15].

Let us note the competent use of the educational potential for the involvement of young people in the activities of the Club of Rome. The Report "Come On! Capitalism, Short-termism, Population and the Destruction of the Planet" itself was published under the authorship of two Co-Presidents of the Club of Rome Ernst von Weizsäcker and Anders Wijkman [16], while the Declaration for Aragon was adopted and signed an hour earlier and with the involvement of the most active and influential youth activists in the field of reclaiming and reframing of the world economy. The main theses of the Aragon Declaration and the Report to the Club of Rome "COME ON!'” completely coincide $[15,16]$ :

a) human activity leads to the collapse of the world economy;

b) there is an urgent need to rethink how governments, businesses, financial systems and youth innovators interact;

c) we need new indicators of economic development (e.g., a Genuine Progress Indicator);

d) there is a need to improve the balance between man and nature, between markets and the law, between private consumption and public goods, between shortand long-term thinking, between social justice and incentives for excellence;

e) advances in technology, mainly aimed to curb greenhouse gas emissions, should be crucial in the new economic philosophy.

Implementation of the Declaration for Aragon and the Report of the Club of Rome "COME ON!" is envisaged to mobilize the active part of the population, including young people and other age groups;

2) in the summer of 2017, the flagship youth "Reclaim Economics" project moved to a new format: the first Club of Rome Summer Academy in Florence, Italy. The Academy was called "Challenging an Unsustainable Economic System" [17]. The idea of the first summer Academy of the Club of Rome was:

a) to destroy the belief in the truth of mainstream economic theories and the stereotypes of the economy that these theories impose;

b) the revival of pluralism of economic discipline.

The Summer Academy considered advanced economic ideas for sustainable development of society. On the one hand, there were students, young specialistseconomists, budding entrepreneurs, young journalists, artists and activists; on the other hand, - leading experts in the field of political economy, business, politicians and journalists took part in their discussion. For seven days (from 7 to 13 of September 2017) at the University of Florence, a total of 120 participants from 25 different countries, discussed what to do and how you can contribute to the restoration and reframing of the existing economic system;

3) expanding the promotion of the flagship "Reclaim Economics" project, the Club of Rome co-organized the Festival for New Economic Thinking on the 19-20 th of October 2017 in Edinburgh (Scotland). The festival brought together organizations and individual representatives whose activities are aimed at improving the ways of teaching, learning and practice of Economics. This Forum was a platform for the exchange of ideas and resources between students, scientists, teachers, entrepreneurs and the general public. The scale of the event, coorganizers and achieved goals can be found on the website of the Festival [18]. It should be noted only that the Festival attracted the attention of the world community specializing in the development of the world economy. The results of the Festival were used at the conference, which was held by the Institute for New Economic Thinking, immediately after the end of the Festival, October 21-23 in Edinburgh (Scotland) [19]. It should be noted that at the conference, the past, present and future of the economic profession were discussed at the level of world leaders already;

4) in May 2018, the Club of Rome co-organized the Wellbeing new Economy Alliance (WE-All) [20]. The decision to establish this organization was made at a conference in Scotland. A group of governments, including Costa Rica, Scotland, Slovenia and New Zealand, had taken the initiative to establish an organization that would develop elements of the new economy. The main goal of the Wellbeing Economy Alliance is to create a sustainable wellbeing economy. Combining international political, economic and scientific organizations of the state and public format Wellbeing Economy Alliance aims to create a centre of influence on the existing economic system in order to restore and reframing it;

5) from 3 to 10 of August 2018 at Neudietendorf (near Erfurt) in Germany, the Club of Rome organized the Summer Academy for Pluralist Economics 2018: Ten Years After The Crash [21]. The Summer Academy criticized the "uncontested" (or "Orthodox") approach of modern economic theories. Alternative approaches to the economy that could be overcome were considered: climate change and environmental destruction; the crisis of the European Union and the rise in right-wing populism; concentration of wealth and chance; tax evasion and youth unemployment. All these "disorders" in society are recognized as a consequence of the mainstream economy, which needs radical changes.

Thus, by the examples of the activities of the Club of Rome, we have considered the second opportunity of educational potential that we have highlighted: the possibility to create a global youth network that has the power to restore and reform the economic system. 
Conclusions. Thus, in the paper, the authors considered the possibilities of educational potential in the restoration and reframing of the existing economic system. By the examples of the activities of the Club of Rome, the authors identified and considered two key opportunities of educational potential:

1. The opportunity to change the world Outlook on the economy on a social scale, i.e. to change the philosophy of the economy.

2. An opportunity to create a global youth network that has the power to rebuild and reform the economic system.

\section{References.}

1. Courvisanos, J., Doughney, J., \& Millmow, A. (Eds.) (2016). Reclaiming Pluralism in Economics. Edited by. Routledge.

2. McCain, R. (2015). Reframing Economics: Economic Action as Imperfect Cooperation. Edward Elgar Pub. 3. McManners, P. (2016). Reframing Economic Policy towards Sustainability. Explored through a case study into aviation. Routledge.

4. Club of Rome (2019). Retrieved from https://www. clubofrome.org/

5. Lovins, H., Wallis, S., Wijkman, A., Fullerton, J., \& Raworth, K. (2018). A Finer Future: Creating an Economy in Service to Life. New Society Publishers.

6. Kravchenko, A., \& Kyzymenko, I. (2019). The Forth Industrial Revolution: New Paradigm of Society Development or Posthumanist Manifesto. Philosophy and Cosmology, 22, 120-128. DOI: 10.29202/phil-cosm/ 22/10.

7. Bazaluk, O. (2017). The Strategies of Systematization of the Theories of Education. The Main Meaning and Features of the Theories of Education of Plato's and Isocrates' Lines. Future Human Image, 7, 11-27.

8. Bazaluk, O. (2017). Plato's and Isocrates' Traditions in the Development of Educational Theories in the History of Culture. Annals of the University of Craiova Philosophy Series, 40 (2/2017), 5-18.

9. Khomenko, O., \& Barna, T. (2019). Zonal-and-Wave Structure of Open Systems on Micro, Mega- and Macrolevels of the Universe. Philosophy and Cosmology, 22, 24-32. DOI: 10.29202/phil-cosm/22/3.

10. Kastrup, B. (2018). The Next Paradigm. Future Human Image, 9, 41-51. DOI: 10.29202/fhi/9/4.

11. Club of Rome (2016). Reclaim Economics. Retrieved from https://www.clubofrome.org/2016/06/03/ reclaim- economics-call-for-participation/

12. Reclaim Economics (2016). Portal i Kwartalnik, czerwiec 6, Retrieved from https://emiddle-east.com/reclaim-economics/

13. Bazaluk, O. (2019). The Revival of the Notion of Arete in Contemporary Philosophy. Schole, 13.1, 198207. DOI: 10.25205/1995-4328-2019-13-1-198-207.

14. Club of Rome (2019). Category: Uncategorized, Retrieved from https://www.clubofrome.org/category/uncategorized/

15. Aragon Declaration for Sustainability (2017). Zaragoza, $4^{\text {th }}$ of May 2017. Retrieved from https://www. clubofrome.org/wp-content/uploads/2017/05/AragonDeclaration-of-Sustainability_English.pdf.
16. von Weizsaecker, E., \& Wijkman, A. (2018). Come On! Capitalism, Short-termism, Population and the Destruction of the Planet. Springer-Verlag. DOI: 10.1007/978-1-4939-7419-1.

17. First Club of Rome Summer Academy (2017). Retrieved from https://www.clubofrome.org/2017/05/17/ summeracademy/\#more-1987.

18. The very first Festival for New Economic Thinking (19-20 Oct. 2017). Retrieved from https://newecon.co/ 19. Institute for New Economic Thinking (2019). https://www.ineteconomics.org/events/reawakening

20. Wellbeing Economy Alliance (WEAll) (2019). Retrieved from https://wellbeingeconomy.org/

21. Summer Academy for Pluralist Economics (2018). Ten Years After The Crash. (n.d.) Retrieved from https://www.exploring-economics.org/en/summeracademy-10-years-after.

\section{Відновлення та рефреймінг економіки: зондування освітнього потенціалу}

\section{I. І. Доброскок, Л. В. Басюк, Н. В. Ржевська, М. Г. Калашник}

Переяслав-Хмельницький державний педагогічний університет імені Григорія Сковороди, м. Переяслав-Хмельницький, Україна, e-mail: mfkoorg@gmail.com

Мета. Розгляд можливостей освітнього потенціалу у відновленні та рефреймінгу світової економіки. Особливу увагу автори приділили розгляду діяльності Римського клубу, на прикладах якої були розкриті можливості освітнього потенціалу 3 реформування світової економіки.

Методика. В якості теоретичної й методологічної основи дослідження автори використали діяльність Римського клубу, авторитетної політичної, наукової та фінансової організації, що однією з головних цілей своєї діяльності розглядає відновлення та рефреймінг світової економіки. Основними методами дослідження є: методи аналізу й синтезу, компаративний аналіз, методи експертних оцінок і наукових узагальнень.

Результати. Автори зробили короткий огляд сучасної літератури, в якій доводиться, що недосконалість сформованої економічної системи є основною причиною зміни клімату, виснаження природних ресурсів, а також зростаючої соціальної нерівності в суспільстві.

На прикладі діяльності Римського клубу автори довели, що відновлення та рефреймінг світової економіки має розпочатися з освіти. У сукупності з політичним, фінансовим і науковим потенціалом, освітній потенціал надав і надає потужний вплив на відновлення та рефреймінг світової економіки. Автори виділили та довели дві ключові можливості освітнього потенціалу:

1. Можливість змінити світоглядну установку на економіку в масштабах суспільства, тобто змінити філософію економіки.

2. Можливість створити глобальну молодіжну мережу, що володіє потужністю відновити й реформувати економічну систему. 
Наукова новизна. Автори виділили й довели дві ключові можливості освітнього потенціалу у відновленні та рефреймінгу світової економіки: 1. Можливість змінити світоглядну установку на економіку в масштабах суспільства, тобто змінити філософію економіки. 2. Можливість створити глобальну молодіжну мережу, що володіє потужністю відновити й реформувати економічну систему.

Практична значимість. На прикладі проектів Римського клубу автори довели ефективність використання освітнього потенціалу у відновленні та рефреймінгу світової економіки. Результати дослідження відкривають можливість широкого використання досвіду Римського клубу як для реформування економічної дисципліни в освітній системі України, так і для реформування економіки України. Робота призначена для теоретичних розвідок і практичного використання студентами, аспірантами та викладачами економіки, а також іншими особами, зацікавленими в реформуванні світової економіки та у сталому розвитку суспільства.

Ключові слова: світова економіка, економічна система, рефреймінг економіки, Римський клуб, освітній потенціал, сталий розвиток, молодіжний pyx

\section{Восстановление и рефрейминг экономики: зондирование образовательного потенциала}

\author{
И. И. Доброскок, Л. В. Басюк, Н. В. Ржевская, \\ М. Г. Калашник
}

Переяслав-Хмельницкий государственный педагогический университет имени Григория Сковороды, г. Переяслав-Хмельницкий, Украина, e-mail: mfkoorg@gmail.com

Цель. Рассмотрение возможностей образовательного потенциала в восстановлении и рефрейминге мировой экономики. Особое внимание авторы уделили рассмотрению деятельности Римского клуба, на примерах которой были раскрыты возможности образовательного потенциала по реформированию мировой экономики.

Методика. В качестве теоретической и методологической основы исследования авторы использовали деятельность Римского клуба, авторитетной политической, научной и финансовой организации, которая одной из главных целей своей деятельности рассматривает восстановление и рефрейминг мировой экономики. Основными методами исследования являются: методы анализа и синтеза, компаративный анализ, методы экспертных оценок и научных обобщений.
Результаты. Авторы сделали краткий обзор современной литературы, в которой доказывается, что несовершенство сложившейся экономической системы является основной причиной изменения климата, истощения природных ресурсов, а также растущего социального неравенства в обществе.

На примере деятельности Римского клуба авторы доказали, что восстановление и рефрейминг мировой экономики должно начаться с образования. В совокупности с политическим, финансовым и научным потенциалами, образовательный потенциал оказал и оказывает мощное воздействие на восстановление и рефрейминг мировой экономики. Авторы выделили и доказали две ключевые возможности образовательного потенциала:

1. Возможность изменить мировоззренческую установку на экономику в масштабах общества, т.е. изменить философию экономики.

2. Возможность создать глобальную молодежную сеть, которая обладает мощью восстановить и реформировать экономическую систему.

Научная новизна. Авторы выделили и доказали две ключевые возможности образовательного потенциала в восстановлении и рефрейминге мировой экономики: 1. Возможность изменить мировоззренческую установку на экономику в масштабах общества, т.е. изменить философию экономики. 2. Возможность создать глобальную молодежную сеть, которая обладает мощью восстановить и реформировать экономическую систему.

Практическая значимость. На примере проектов Римского клуба авторы доказали эффективность использования образовательного потенциала в восстановлении и рефрейминге мировой экономики. Результаты исследований открывают возможность широкого использования опыта Римского клуба как для реформирования экономической дисциплины в образовательной системе Украины, так и для реформирования экономики Украины. Работа предназначена для теоретических разведок и практического использования студентами, аспирантами и преподавателями экономики, а также другими лицами, заинтересованными в реформировании мировой экономики и в устойчивом развитии общества.

Ключевые слова: мировая экономика, экономическая система, рефрейминг экономики, Римский клуб, образовательный потенциал, устойчивое развитие, молодежное движение

Рекомендовано до публікацї докт. екон. наук С.А.Полішуком. Дата надходження рукопису 18.03.18. 